\title{
Improving Client Satisfaction in Construction Projects: the case of Saudi
}

\section{Arabia}

\begin{abstract}
Purpose: Client satisfaction is often associated with performance in the construction industry. Organisations that achieve very high ratings of client satisfaction improve their positions in the marketplace. Many clients are often dissatisfied with their project outcomes. Hence a study was carried out to examine the ways project managers and/or contractors perceive the subject of client satisfaction.
\end{abstract}

Design/methodology/approach: The study applied qualitative research methods and followed the interpretivist paradigm and inductive research approach. Thirty interviews were conducted with construction project managers and evaluated by thematic analysis.

Findings: The study identified five prominent factors which the project managers perceived to impact on client satisfaction which are: effective financial management; use of skilled workers; use of advanced technology; customer relation management and time management. Other contributors to client satisfaction include effective team leadership, project monitoring, communication and adequate knowledge and skills.

Research limitations/implications: Data collection was limited to Saudi Arabia but the general methodology used and some of the findings may be applicable beyond this country.

Practical implications: The findings provide a more informed basis of attaining greater client satisfaction by contractors especially within and possibly beyond Saudi Arabia. Also, contractors can directly inquire from clients about their satisfaction following project completion.

Originality/value: A project manager's perspective and Saudi Arabian orientation of client satisfaction is presented. Also, insight into the multi-faceted nature of the factors influencing client satisfaction is provided. 
Keyword: Clients, perceptions, project management, Project impact assessment, Project performance, Customer satisfaction, Saudi Arabian construction.

\section{INTRODUCTION}

The client is the owner of a (construction) project or buyer/seller of products or services (Haddadi, Johansen and Andersen, 2016). In construction, the client is often taken as the person or organisation that procured a project and this paper is based on this understanding. The satisfaction of clients is characterised by the delivery of services or products that match or exceed their expectations (Rashvand and Majid, 2014; Ahmed and Kangari, 1995). Clients' satisfaction is thus based on understanding their requirements (Soetanto and Proverbs, 2002; Oppong, Chan and Dansoh, 2017; Rashvand and Majid, 2014) and then meeting these (Tang et al., 2003). As clients' are continually dissatisfied (Bowen et al., 1997) our research sought to study how contractors are addressing the issue.

The construction industry of Saudi Arabia is growing fast but clients there are less involved in the procurement decisions on the premise that their consultants and project managers are experts whose actions and decisions are okay (Trigunarsyah and Solaiman, 2016). This practice places project managers in a more strategic role of driving the activities and outcomes of construction projects, i.e. their actions can make or mar client satisfaction (Alzahrani and Emsley, 2013; and Nikakhtar et al. (2015). Al-Kharashi and Skitmore (2009) suggests inadequacy in up to $70 \%$ of public construction projects in Saudi Arabia concerning e.g. communication and meeting of deadlines. This shortcoming is able to cause dissatisfaction on both sides of a construction contract. Hence our research studied client satisfaction in Saudi Arabia from the perspectives of both clients and contractors. However, this article reports the 
views of the project managers (contractors), while a sequel concentrates on the perspective of clients.

The indicators of client satisfaction include: the number of complaints issued to project managers and their ability to solve these promptly (Sarhan et al., 2017); performing work successfully (Oppong, Chan and Dansoh, 2017; Saunders et al., 2016); supporting clients and fulfilling their financial requirements (Soetanto and Proverbs, 2002); effective relationship and leadership qualities (Wu et al. 2016); contractors' zero rework, zero rectification, zero deviation, working within budgets and conforming to standards and specifications (Arslan and Kivrak, 2008; Zhou, Goh and Li, 2015); effective waste management, honesty, trustful relationships and ensuring that quality raw materials and effective processes are used (Nguyen and Watanabe, 2017; Thomas, 2017).

Studies have sought to understand construction client satisfaction. For instance Rasvand and Majid (2014) reviewed the critical criteria for client satisfaction; Tang et al, (2003) identified the factors that contribute to client satisfaction in the context of engineering consulting service; Ahmed and Kangari (1995) prioritised the factors that contribute to client satisfaction; and Mbachu and Nkado (2006) explored how to measure the level of client satisfaction by using multi-attributes. However, most of these studies focus on assessing client satisfaction while less attention has been paid to how contractors perceive and pursue the subject matter.

Client satisfaction depends, in part, on the perceptions of project managers (Omonori and Lawal, 2014). This is particularly so because, project managers have to understand the requirements of clients and then deliver projects that match these. However, the limited evidence about project managers' perceptions of client satisfaction signifies a gap (Kärnä and 
Junnonen, 2016; Manley and Chen, 2015). Hence the research question which was addressed in our study was: How do Project Managers in the Saudi Arabian construction industry perceive client satisfaction? Understanding these perceptions is important because they form the basis on which the contractors will deliver projects and inadvertently satisfy clients. Hence the contractors' perceptions, if studied, could be paired with clients' views. The authors intend to ultimately pair the perspectives of the two sides. Suffice to report the views of the contractors for now.

The next section reviews literature, and is followed by the research methodology. The findings of the study are then presented and discussed before wrapping up.

\section{LITERATURE REVIEW}

Client satisfaction is based on meeting or exceeding their expectations (Raham and Alzubi, 2015); thus understanding these expectations is vital (Soetanto and Proverbs, 2002; Durdyev et al, 2018). The project brief and tender/contract documents provide a significant indication of clients' expectations (Boyd and Chinyio, 2006); and having understood these documents (Omonori and Lawal, 2014), a project manager's experience, knowledge, capability and efficacies will ensure that the final product delivered meets the requirements of the client (Soetanto and Proverbs, 2002; Kumar and Reinartz, 2018) and thus yield satisfaction to them.

The literature links client satisfaction with: 1) many attributes, and 2) project success. Sometimes the distinction between the two is blurred and this review is presented that way; particularly that client satisfaction in the construction industry is often associated with successful project delivery (Gunning, 2000; Soetanto and Proverbs, 2004). 
Effective collaboration, use of project management approaches and communication between the project manager and other stakeholders enhance client satisfaction (Meng, 2012). The decision-making processes of project managers help in managing their activities, completing projects successfully and fulfilling their clients' requirements (Meng, 2012). The processes, activities and interests of the multi-stakeholders in a project do influence project outcomes as well (Walker, 2015). Further, Walker (2015) indicates that project manager's skills and perceptions in managing different construction activities effectively contribute to project success and client satisfaction. Meng (2012) agrees with this view, explaining that the perceptions and ability of project managers can correctly identify any undesirable aspects in construction works and help remove faulty aspects that do not meet a client's requirements.

Project team members are required to maintain good relations with each other and with clients, as this helps in fully understanding and completing projects successfully (Chan et al., 2004; Alinaitwe, Apolot and Tindiwensi, 2013). Mutual co-operation and coordination of project activities between project participants helps in the achievement of client satisfaction (Kärnä, 2004; Jha and Iyer, 2007).

Project managers can enhance communication such that all activities are understood adequately and requirements fulfilled. Al-Kharashi and Skitmore (2009) suggests that 70 per cent of public construction projects in Saudi Arabia are characterised by inadequate communication and not meeting deadlines: providing opportunity for client dissatisfaction.

The aspects of project costs, delivery time and quality are amongst the clients' satisfaction criteria (Meng, 2012; Alinaitwe, Apolot and Tindiwensi, 2013). The full perception of these trio helps greatly in addressing issues, such as financial deficiencies on the part of contractor 
or client and unavailability or inadequacy of equipment and tools for the project; thus avoiding project delays and cost overruns (Alinaitwe, Apolot and Tindiwensi, 2013).

Arslan and Kivrak (2008) highlighted several crucial factors that affect client satisfaction i.e. the work performance, personal skills and management capabilities of project managers in relation to achieving the budgets and schedules. The skilfulness of a contractor would include the use of skilled workers (Gruneberg, 1997; Jha and Iyer, 2007) and advance technologies (Nguyen, Ogunlana and Lan, 2004).

Other key attributes that enable project managers to complete their project activities successfully and achieve a higher degree of client satisfaction include the following of known standards (Pheng and Teo, 2004), good experience and behaviour (Soetanto and Proverbs, 2002; Meng, 2012) proper monitoring of projects and providing timely feedback to clients (Alzahrani and Emsley, 2013; Demirag et al., 2004). These attributes and actions promote the quality and standards of work, better communication and team leadership approaches, and consequently limit project cost overruns and delays (Berntsen, 2016). Keeping a track record and providing management support by contractors further contribute towards client satisfaction (Alzahrani and Emsley, 2013; Nikakhtar et al., 2015).

\section{Clients' requirements are dynamic}

Most often, success factors, and by extension client satisfaction criteria, are established at the beginning of a project and tend to remain fixed whereas some of these evolve over time and are often not updated (Thomson, 2011). Changing market circumstances can trigger rapid changes in clients' requirements (Alzahrani and Emsley, 2013). In order to achieve client satisfaction therefore, project managers must continually pay attention to clients' dynamic 
requirements and this can be facilitated by maintaining good relationships with them (Jha and Iyer, 2007). Meanwhile a clients' express requirements could be accomplished by a contractor, yet they may be dissatisfied or partially satisfied due to this fluidity (Mbachu and Nkado, 2006). Further, clients, consultants (designers) and contractors could perceive success criteria differently (Campbell and Zhu, 2008) and this may impact on their differing assessments of project success and by extension client satisfaction (Lai and Lam, 2010).

\section{Determining client satisfaction}

A universal tool of assessing client satisfaction does not exist (Torbica and Stroh, 2001). However, clients' satisfaction can be checked:

- directly by making inquiries with them (Soetanto et al., 2001); and,

- indirectly by getting either or both i) repeat business (re-use) and ii) referrals from a client (Fornell, 1992).

Referrals and re-use of contractors are especially more applicable to private sector procurement, as most public sector procedures tend to follow strict competitive rules that may not allow these practices.

\section{Perception of client satisfaction}

Client satisfaction is associated with many attributes (Boasson and Wettestad, 2016) and the dynamic nature of clients' requirements makes all these attributes crucial: each at some stage/s of a project (Omonori and Lawal, 2014; Al Kharashi and Skitmore, 2009). Achieving these attributes as a guide generates trust, greater confidence, use of more effective work procedures, improved quality of project outcomes, meeting of project deadlines and consequently client satisfaction (Omonori and Lawal 2014; Mackey and Gass, 2015). Meanwhile, the competence of a construction project manager contributes immensely to the achievement of clients' 
expectations (Donohoe and Brooks, 2007). One dimension of this competence was studied empirically i.e. the perception of clients' needs.

In view of the many yardsticks of client satisfaction, our study explored how construction project managers perceive and approach the subject matter, with a special focus on Saudi Arabia. This focus was surmised from Arslan and Kivrak (2008) and Al-Kharashi and Skitmore (2009) who raised the crucial aspect of project managers' perceptions towards deploying techniques for improving client satisfaction in especially the Saudi Arabian construction industry. Supporting our study is the opinion by Durdyev et al. (2018) that client satisfaction has not been given adequate attention.

\section{THE METHODOLOGY}

Our study followed a systematic research procedure, i.e. reflected a study paradigm, design, data collection and analysis methods (Kuada, 2012). The interpretivist research option was adopted, as the nature of the study required an in-depth exploration of the topic. Extrapolating from Krauss (2005): 1) the reality of the perceptions of project managers on client satisfaction could be included in the study constructs and 2) the researchers had greater flexibility and wider perspective on the focus of the study.

The deductive and inductive study approaches are available (Jonker and Pennink, 2010). The inductive research approach was suitable for the study as it followed the interpretivism paradigm; and was effective in gathering generalised information on the perceptions of project managers. This approach also warranted flexibility and involvement of theories in the study (Bokhari and Qureshi, 2016). 
Two types of research design are the exploratory and descriptive (Scruggs and Mastropieri, 2006). Using the exploratory option, generalised information was gathered regarding the focus of the study and the researchers were able to (Supino and Borer, 2012; de Carvalho, Patah and de Souza Bido, 2015): increasingly familiarise with and gain the attention of the participants.

The method of collecting primary data is crucial (Wetcher-Hendricks, 2011). In order to explore the views of the participants in a more detailed manner the interview method was chosen. The non-probability purposive sampling method was adopted, which was effective and beneficial in terms of getting the appropriate persons to discuss the subject matters. The study complied fully with our university's ethical procedures. The informed consent of each participant was obtained before each interview.

Following guidance from Yin (2013) and Merriam and Tisdell (2015) the interview questions were drafted to be easily understandable, not misleading and not tilting the responses of the interviewees in a particular direction. The interview guide had the central focus of client satisfaction and practices which contractors use to achieve it in the Saudi Arabian construction industry. The interview guide had a baseline of 38 questions: 8 of these on biographic information and the other 30 concerned client satisfaction, e.g. the impacts of advanced technology, use of skilled workforce, completion of projects on time and what construction companies should do to improve client satisfaction.

The mostly unstructured interviews were conducted face-to-face where 'detailed responses were retrieved' (Olsen, 2011). The sample size of interviews should generate adequate information (Yun, Won and Park, 2016) and yield saturation (Bryman, 2016) which was achieved with 30 interviews. 
Thematic analysis was utilised, which is critical in nature and yields valid results (Guest, MacQueen and Namey, 2011). A dialectic process of description, analysis and interpretation (Ngulube, 2015) was followed. The description process which gives a general overview of the results began with the identification of the main factors that influence client satisfaction. All the interviews were transcribed verbatim and the contents were read and coded to identify the emerging themes. The codes for the themes were developed using two criteria: 1) the interview questions; and 2) the themes that emerged from the analysis of the transcribed interviews. The application of the inductive approach in the analysis involved 'the cross evaluation of the revealed practice with what has been reported in literature' (Dubois and Gadde, 2002). Using the Nvivo software, factors relating to similar themes were grouped into similar categories which identified the key issues on which attention must be paid in the subsequent and more detailed analysis.

The next step of the dialectic process, the analysis stage, identified the interrelationships between the factors affecting client satisfaction. The outcome of the initial grouping of factors was in this regard further refined through the complex query function of Nvivo to ensure that the right relationships were created. Meanwhile, a conceptual framework was developed from the literature review and prior to the interviews. This framework had a number of main themes which concerned some practices of construction firms and factors influencing client satisfaction and these served as an initial basis of building the empirically derived themes in the research. However, the final set of themes emerged from the analysis of the empirical data. Further, sub-themes were identified in the analysis phase, e.g. reasons for client dissatisfaction, means of determining client satisfaction and common issues faced by clients. 
The third stage of the dialectic process of analysis, the interpretation, identified the connections between sub and main themes and reasons for their interrelationships. Finding these reasons required going beneath the surface to discover why the particular results were reached.

The core themes that emerged from the analysis were: 1) means of determining client satisfaction; 2) perceived factors impacting on client satisfaction; and 3) prominent influences on client satisfaction. The results are presented on the basis of these three main groupings. These final outcomes are presented in the results section below.

\section{Background of the research participants}

The 30 interviewees work for small (10\%), medium (67\%) and large (23\%) companies that carry out large building and civil engineering works (48\%), medium sized projects (43\%) and small schemes (9\%). Their range of construction experience was: over 7 years (37\%); between 1-7 years $(60 \%)$ and less than one year (3\% - whose views were not unique). Each interview lasted about 30 minutes.

\section{RESULTS AND DISCUSSION}

In this section, some viewpoints of the interviewees are quoted verbatim (in italics) for emphasis. The interviewees have been anonymised as Numbers 1 to 30 for confidentiality.

\section{Means of determining client satisfaction}

The responses of the interviewees indicated three main ways of establishing client satisfaction i.e. re-use of the contractor by the client; referral by the client; and making a direct inquiry. Fifteen project managers (50\%) interpreted referrals by their clients as evidence of the latter's satisfaction. According to interviewee No.19, "if the client is satisfied, he orders our services again and nominates us to his acquaintances." 
The second means of assessing client satisfaction is through 'repeat businesses'. According to No.7, "Ordering our services again is the most important factor" to determine that a client is satisfied.

The third means of determining client satisfaction was to specifically make a direct enquiry. According to No.12 "after finishing the project, we contact our clients in order to ask about the extent of their satisfaction."

Some interviewees indicated using all the foregoing three avenues. For example, No.15 remarked that:

Referring our company to his acquaintance is the most important indicator of satisfaction. Ordering our services again is another indicator that he's satisfied. We also call him after delivering the project in order to ask about the level of satisfaction.

While the foregoing findings agree with Fornell (1992) and Soetanto et al. (2001), Ahmed and Kangari (1995) suggests that clients are often critical of contractors hence the later tends to not seek the former's opinion about satisfaction. However, our interviewees seem to indicate a regular check with their clients about satisfaction. This proactive stance by the interviewees might be attributable to the understanding that client satisfaction is very crucial to survival in business (Oliver and Linda, 1981). Further, the aspect of referrals would be more applicable to private sector clients, as the practice may not be feasible in public sector procurement. 


\section{Perceived factors impacting on client satisfaction}

The analysis teased out 8 mostly multi-faceted factors which the interviewees thought had both direct and indirect influences on client satisfaction. Three of these which agree with Ahmed and Kangari (1995) concerned the use of effective financial management, skilled labour and advanced technologies. The others were the: use of known standards; attitudes of project managers; knowledge, skills and competencies of project managers; greater teamwork and communication in projects; and, full understanding of the project brief.

\section{Effective financial management}

Effective financial management enhances an organisation's ability to operate within budget and reduce the need to over-rely on loans. An interviewee remarked that “...effective financial management is so important because it saves money and effort" and according to No.18:

Clients care about their investment and money. They need to be assured that their project will be handled properly and effectively. This also avoids the company having any delays or troubles due to insufficient financing for the project. This ultimately can lead to convincing more prospective clients to trust this company.

The contribution and importance of financial management towards completing projects successfully had been identified by Edum-Fotwe and McCaffer (2000), Al-Joburi, Al-Aomar and Bahri (2012) and Alinaitwe, Apolot and Tindiwensi (2013). When projects are completed within budget, the clients tend to be satisfied.

Some interviewees however thought that financial management had no effect on client satisfaction. According to No.13, "There is no relationship between them. Client satisfaction has nothing to do with efficient financial management. The most important factor for client 
satisfaction is quality." No.2 also suggested that: "Effective financial management affects our company and not the clients."

The discordant views above are matched by literature, e.g.: while Edum-Fotwe and McCaffer (2000) indicate the essence of financial prudence, Briscoe, Dainty and Millett, (2001) report that some construction industry supply chains rank it low.

\section{The use of skilled labour}

A skilled workforce ensures a timely delivery of projects, high quality outputs, reduction in waste and mistakes, proper implementation of client's requirements and reduced issues, risks, and health and safety challenges. No.3 pointed out that: "Skilled labour can finish the project in record time. They do their job efficiently. That is what we need as a company and clients as well." No.7 added that: "Skilled labour can avoid safety troubles for us. They have experience regarding waste and saving raw materials. They also don't need training, so this saves trainers' wages. They can offer high-quality work at a lower price". Time is one of the factors influencing client satisfaction (Ahmed and Kangari, 1995) and using a skilled workforce does contribute to reducing wastes, mistakes, risks, accidents and time on the job; and delivering high quality outcomes and better performance generally (Gruneberg, 1997; Jha and Iyer, 2007).

Some interviewees opined an additional advantage of using a skilled workforce. For example, No.19 said that: Hiring a skilled and well-trained workforce is very important in order to impress clients. This may be signalling some contractors' proactive efforts towards attaining client satisfaction. 


\section{The use of advanced technology}

The use of advanced technology improves efficiency in productivity and yields: time savings, reduction of waste, higher quality of outputs, reduced cost as well as improved reputation, competitiveness and profit for the contractor. Figure 1 illustrates how this and other factors are multi-faceted. No.11 reported that: "We also utilise technologically advanced machines which help us achieve high-quality projects in a short time. These machines save time and effort. They can also boost our reputation."

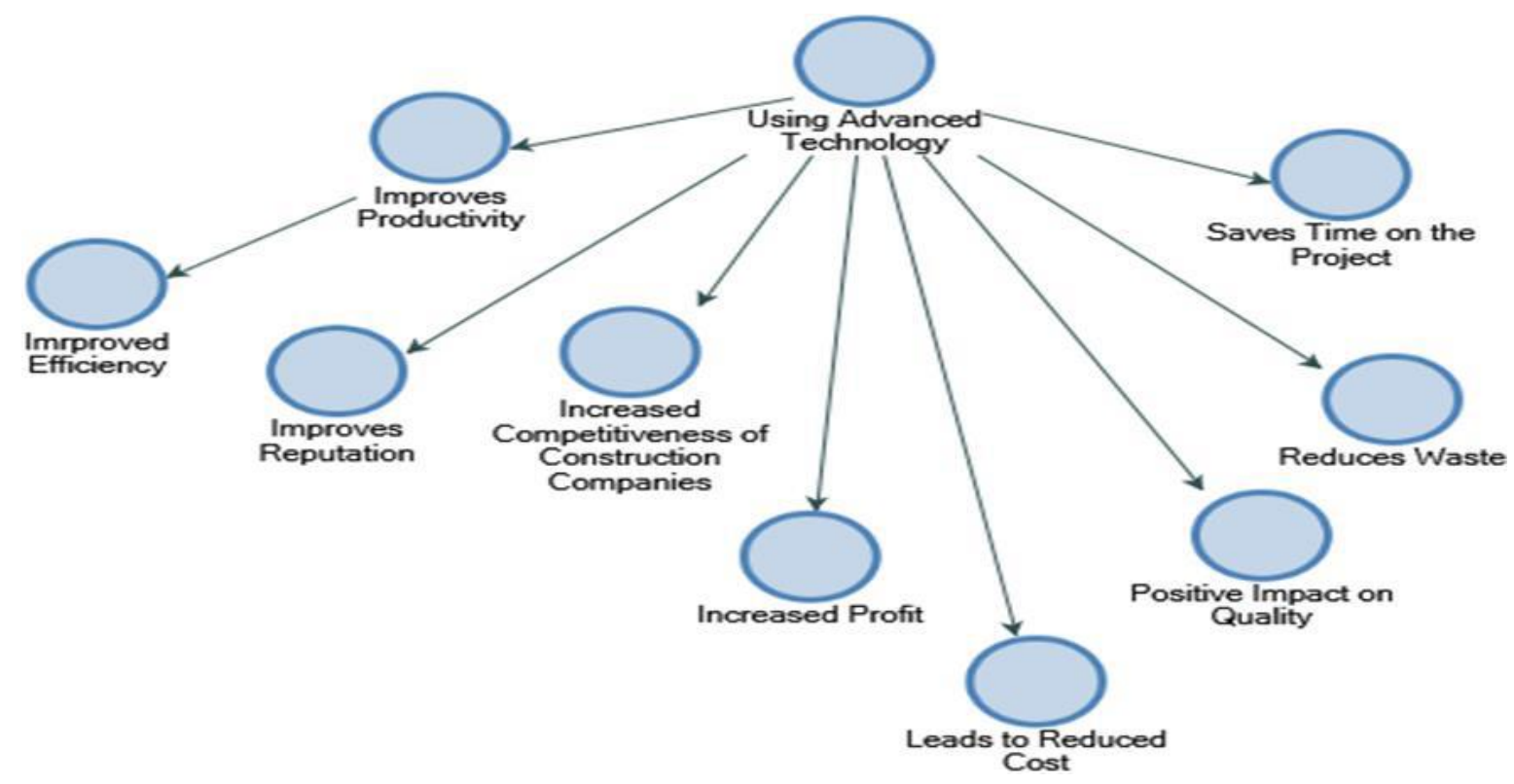

Figure 1: Benefits of using advanced technology in construction project delivery

Overall, the use of advanced technologies has a positive impact on both the contractor and client satisfaction. Moreover, the added human element in the use of advanced technologies can amplify the benefits further (Shan et al., 2011). Capital productivity is an element of productivity attributable to the use of technology (Loosemore, 2014), which improves productivity and efficiency (Nguyen, Ogunlana and Lan, 2004). 
However the price of using advanced technology is a concern, as observed by No.23 that: "their cost is high. For example, if the project is on a large scale, we use expensive equipment, because the project size covers its cost. When we constructed the tower project we bought costly equipment". No.29 explained that: "They are sometimes expensive. But on the other hand, they can cover their initial high cost".

\section{Use of known standards}

The contractors implement certain standards or practices to partly ensure client satisfaction. Examples of these are the Saudi Building Code, ISO 9002, total quality management (TQM), Business to Business and Business Process Re-engineering. The Saudi Building Code, according to No.16, "helps us to ensure the buildings we put up meet all the quality requirements of Saudi Arabia. If a client can see that you meet the requirements of the code, it gives them some level of assurance about your work.” No. 9 corroborated that “... once they can see that your processes are in line with the requirements of TQM, they are well convinced that you will deliver the project to their satisfaction as your processes ensure quality is put at the forefront of all your projects." Pheng and Teo (2004) found that complying with construction standards such as TQM results in client satisfaction, among other benefits.

Other practices adopted by the contractors to satisfy clients include the use of Business Process Reengineering and Business to Business for better management and improved performance on projects; and training of employees to ensure better communication between clients and contractors. One interviewee stated that "the level of communication between the project team impacts on good practices". Lindhard and Larsen (2016) observed that knowledge sharing and effective communication improves project performance. 
Using standards ensures product quality, safety and timely completion of projects too. An interviewee pointed out that "if the contractor fails to deliver the project on time, he may face fines and obligations. Time is a big challenge for contractors." The implementation of standards as discussed above connects it with communication, safety, quality and duration of projects. This shows how many attributes and sub-attributes combine, often in a convoluted manner, to impact on client satisfaction. This makes client satisfaction quite intricate and worth managing well.

\section{The attitudes of project managers}

Some of the project managers thought that their behaviours influenced client satisfaction as well. No.2 explained that "contractors should care about honesty, devotion, commitment, and quality". A culture of honesty is quite rewarding. According to No.8, "They should build bridges of trust and communication with their clients. This has a tremendous effect on their profit and reputation." The research found out that a positive attitude facilitates successful project completion, minimises material waste and conserves resources. No.1 explained how 'project managers usually have a careless attitude regarding the management and allocation of resources and project planning. This leads to higher wastage and causes a significant delay in project completion.'

The views of the interviewees are corroborated by literature (e.g. Soetanto and Proverbs, 2002; Meng, 2012) which emphasises how the experience, behaviour and perception of the project manager influences the successful completion of projects and ultimately, client satisfaction. Project managers should thus approach their endeavours with the right attitude which their clients expect. 


\section{The knowledge, skills and competencies of project managers}

The personal and professional goals, ethics, knowledge and skills of project managers influence successful project delivery and by extension client satisfaction (Peppers and Rogers, 2016; Kumar and Reinartz, 2018). In this context, No.7 also stated that; "if the project manager has a clear and correct perception regarding quality and its importance while delivering the project, the client satisfaction tends to be higher. This is because with such perception he is able to ensure the effective fulfilment of the key quality standards regarding the raw material, project planning, waste management, cost management and process requirements". Other interviewees expressed similar views. Some literature (e.g. Soetanto and Proverbs, 2002; Walker, 2015) suggests that a focused and positive perception of contractors and their project managers in respect of time, cost and quality of product can significantly ensure higher client satisfaction.

\section{Greater teamwork and communication}

Projects are delivered by different teams that need to cohere with each other to avoid clashes. As pointed out by No.6: "effective teamwork and management, clear and transparent communication between team members and client service are highly beneficial in delivering the project successfully and thus delivering higher client satisfaction." This view highlights how mutual coordination and cooperation are practical and helpful for organising the operations and processes of a project (Hazır, 2015); implementing team leadership, project monitoring and feedback (Alzahrani and Emsley, 2013; Demirag et al., 2004) and contributing to higher client satisfaction (Alinaitwe, Apolot and Tindiwensi, 2013; Kärnä, 2004). 


\section{Understanding the project brief}

To a contractor, the project brief represents the contract and other project information given to them to signify what the client expects them to accomplish. In the traditional type of procurement, this brief comes via the: 1) invitation to tender, 2) subsequent tender documents and 3) complete contract documents. No.11 explained that, "a positive perception regarding the work and project plays a key role in successful project completion." No.1 concurred that "effective knowledge about the requirements of the client's needs helps the project manager and contractor in developing and following an effective response strategy that can help in enhancing project quality and lead to higher client satisfaction in the Saudi construction industry."

Literature (e.g. Meng, 2012; Alinaitwe, Apolot and Tindiwensi, 2013; Omonori and Lawal 2014) supports the contribution of accurate perception towards proper project execution and client satisfaction. Understanding the project brief is the starting point towards client satisfaction.

\section{The prominent influences on client satisfaction}

Five of the strategies and tactics discussed above were cited more frequently by the interviewees, i.e.: financial management, use of advanced technology, use of skilled workforce, customer relationship management and time management. As shown in Figure 2, most participants $(87 \%)$ thought that financial management was very essential for effective project management as it helps in managing budget and resources as well as stabilising the cash-flow. 


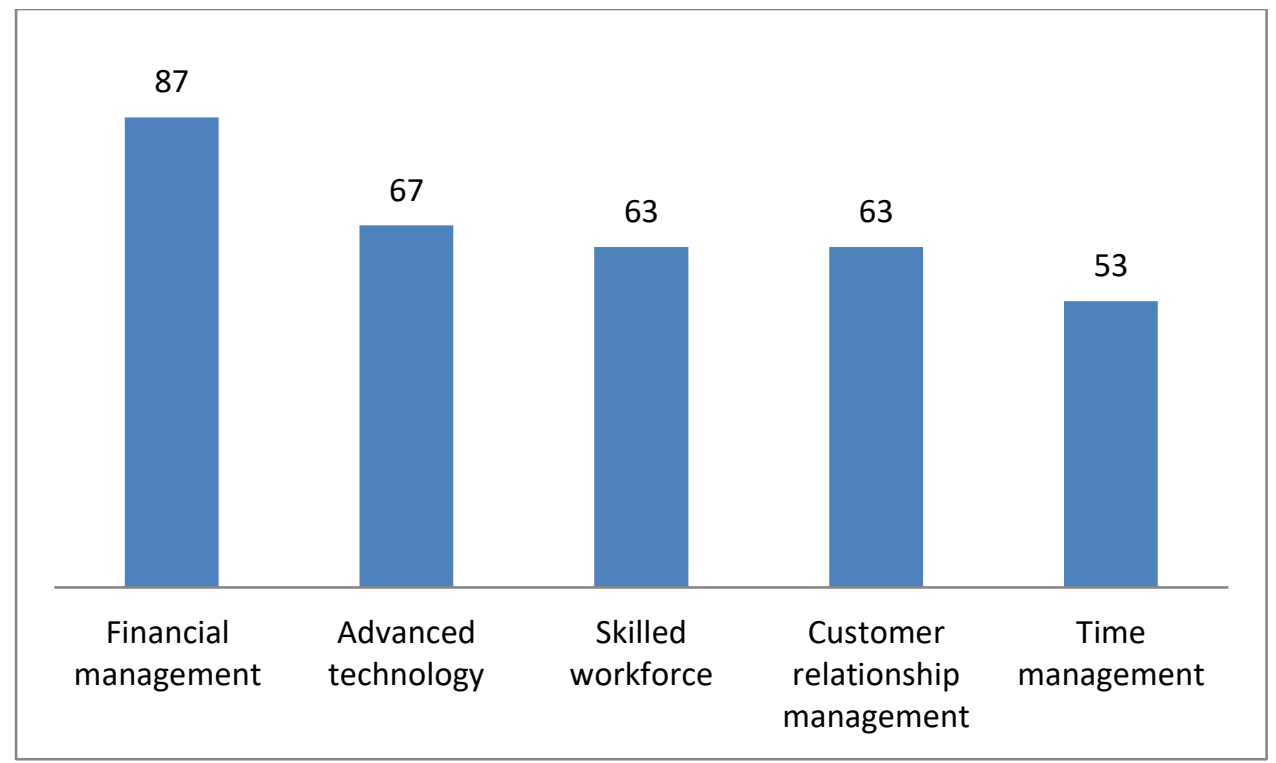

Figure 2: Key influences on client satisfaction

Many interviewees (67\%) thought that a skilled workforce was vital for managing the project successfully, towards ensuring client satisfaction. Several interviewees $(63 \%)$ felt that the use of advanced technology was a big factor in client satisfaction. Further, $63 \%$ of the respondents emphasised the link between customer relationship management (CRM) and client satisfaction; as it allows them to continuously communicate with their clients effectively and understand their requirements fully. Jha and Iyer (2007) associated relationship management with project success attributes and thus an indirect contributor to client satisfaction. Some interviewees (53\%) considered time management to be very vital for delivering projects successfully to enhance client satisfaction.

\section{Overview of the results}

It can be deduced from the foregoing that both the secondary and primary data reflect similar views virtually. Both sets of data indicate that client satisfaction has many attributes. These several factors and associated practices and measures for client satisfaction are all crucial (Omonori and Lawal, 2014; Al Kharashi and Skitmore, 2009) and often interlinked. The client 
satisfaction attributes are thus multifaceted, making it unwise to look at one contributor in isolation.

\section{CONCLUSIONS}

The aim of the study was to understand how to improve construction client satisfaction in Saudi Arabia through the perceptions and practices of project managers in that country. The findings indicate that effective financial management helps contractors to complete projects successfully and indirectly satisfy their clients. Literature and few of the interviewees however felt that financial prudence benefited the contractor essentially as opposed the client.

The research participants also perceived that using advanced technology and skilled workers contributes to timely project completion and good quality of product, and by extension, client satisfaction. Contractors are willing to invest on technology in this regard. The study also found out that contractors adhere to established standards and regulations such as TQM and ISO 9002; and pay attention to effective communication and behavioural actions such as trust, honesty and transparency; which are all perceived to have an impact on clients' satisfaction.

The project managers interviewed opined how they have clear views of what it takes to achieve greater client satisfaction. Some of their opinions were that effective team leadership, project monitoring, better and timely communication and feedback along with experience, knowledge and interactions with stakeholders contribute to client satisfaction. The study further established that the experience, knowledge, behaviour, intention and attitudes of the project managers do have a positive influence on project delivery and cost, quality of product and client satisfaction. 
The study identified five prominent factors which the project managers perceived to impact on client satisfaction in especially Saudi Arabia. These were: effective financial management; use of skilled workers; use of advanced technology; customer relation management and time management. Each of these five factors was identified by over $50 \%$ of the interviewees. Another significant finding of the research is the prominent role played by good attitudes and behaviours which were perceived as one key basis on which clients will feel satisfied with project delivery and outcomes.

The attributes that influence client satisfaction are multifaceted. Their respective influences could also vary as a project develops. Further newer attributes could emerge in the course of a project to also influence client satisfaction. This dynamism of client satisfaction attributes is similar to that of risk factors in a project. However, while risk management is more prominent and well-rehearsed and researched in the construction sector the management of client satisfaction is rather evolving. More studies of the subject matter are thus very worthwhile.

This study contributes to knowledge and practice on how to improve construction client satisfaction in Saudi Arabia, as follows: Firstly, the identification of the factors that influence client satisfaction such as financial management, adhering to standards and regulations, and use of skilled workers among others, would direct future action to be taken to improve client satisfaction in the management of construction projects. By focusing on these factors and achieving them, the contractors would be able to improve on client satisfaction on different types of projects. Secondly, the study established new insight on how construction project manager's perceptions and attitudes influence client satisfaction especially in the context of Saudi Arabia. 
The findings contribute towards improving construction project delivery in Saudi Arabia. The findings also contributes to greater client satisfaction in that country. Contractors that are planning to carry out construction business in Saudi Arabia are now furnished with knowledge on how to improve client satisfaction through our findings. It is worth noting that this is among the first studies to explore the perceptions of project managers on client satisfaction. Although the empirical study was limited to Saudi Arabia, the evidence gathered there could be adopted and used as a lens to direct future actions towards improving client satisfaction in construction projects in other countries.

Only thirty project managers were interviewed, however, there was a consistency in their views and suggestions; and they seem to agree that client satisfaction is highly important. Further, there was an underlying but subdued conjecture that, project success ensures client satisfaction. Both the literature and empirical findings support this conjecture. Where a project is completed successfully e.g. on time, within budget and by using skilled labour and advanced technologies, the project managers thought that the client was by extension satisfied. It may be that some additional factors influence client satisfaction but are unknown to the contractors. Such additional factors would best be investigated with clients. Hence, another set of interviews was conducted with clients to establish their own perspective of satisfaction but this other dimension of the study is outside the scope of the present article.

\section{ACKNOWLEDGEMENT}

The research which informed this paper was funded as a PhD studentship, which was granted to the first author by the Government of Saudi Arabia. The funding is greatly appreciated. 


\section{REFERENCES}

Ahmed, S.M. and Kangari, R. 1995. Analysis of client-satisfaction factors in the construction industry. Journal of Management in Engineering, 11(2), pp. 36-44.

Al-Joburi, K.I.; Al-Aomar, R. and Bahri, M.E. 2012. Analyzing the Impact of Negative Cash Flow on Construction Performance in the Dubai Area. Journal of Management in Engineering, 28(4), pp. 382-390.

Al Kharashi, A. and Skitmore, M. 2009. Causes of delays in Saudi Arabian public sector construction projects. Construction Management and Economics, 27(1), pp. 3-23.

Alinaitwe, H., Apolot, R. and Tindiwensi, D. 2013. Investigation into the causes of delays and cost overruns in Uganda's public-sector construction projects. Journal of Construction in Developing Countries 18(2), pp. 33 - 43.

Alzahrani, J.I. and Emsley, M.W. 2013. The impact of contractors' attributes on construction project success: A post construction evaluation. International Journal of Project Management, 31(2), pp. 313-322.

Arslan, G. and Kivrak, S. 2008. Critical factors to company success in the construction industry. World Academy of Science, Engineering and Technology, 45(1), pp. 43-46.

Berntsen, L. 2016. Reworking labour practices: on the agency of unorganized mobile migrant construction workers. Work, Employment and Society, 30(3), pp. 472-488.

Boasson, E.L. and Wettestad, J. 2016. EU Climate Policy: Industry, policy interaction and external environment. London: Routledge.

Bokhari, A.S. and Qureshi, R.J. 2016. Business Process Re-Engineering in Public Administration of the Kingdom of Saudi Arabia. International Journal of Information Engineering and Electronic Business, 8(4), p. 10-17.

Bowen, P.A.; Hindle, R.D.; and Pearl, R.G. 1997. The effectiveness of building procurement systems in the attainment of client objectives. In C.H. Davidson (Ed.) Procurement - the 
Way Forward: Proceedings of the CIB W-92 Montrèal Conference, CIB Publication 203, Université de Montreal, Montrèal, Canada, pp. 39-49.

Boyd, D. and Chinyio, E. (2006) Understanding Construction Clients. Oxford: Blackwell Science.

Briscoe, G., Dainty, A.R. and Millett, S. 2001. Construction supply chain partnerships: skills, knowledge and attitudinal requirements. European Journal of Purchasing and Supply Management, 7(4), pp. 243-255.

Bryman, A. 2016. Social research methods. Oxford: Oxford University Press.

Campbell, F. and Zhu, C. 2008. Stakeholder perception of construction site managers' Effectiveness. Construction Management and Economics, 26(6), pp. 579-590.

Chan, A.P., Chan, D.W., Chiang, Y.H., Tang, B.S., Chan, E.H. and Ho, K.S. 2004. Exploring critical success factors for partnering in construction projects. Journal of Construction Engineering and Management, 130(2), pp. 188-198.

de Carvalho, M.M., Patah, L.A. and de Souza Bido, D. 2015. Project management and its effects on project success: Cross-country and cross-industry comparisons. International Journal of Project Management, 33(7), pp. 1509-1522.

Demirag, I.; Dubnick, M. and Khadaroo, M.I. 2004. A framework for examining accountability and value for money in the UK's private finance initiative. The Journal of Corporate Citizenship, Sheffield(Iss.15 - Autumn): pp. 63-76.

Dubois, A. and Gadde, L. E. 2002. Systematic combining: an abductive approach to case research. Journal of Business Research, 55(7), pp. 553-560.

Donohoe, S. and Brooks, L. 2007. Reflections on construction management procurement following Great Eastern Hotel Company v. John Laing. Construction Management and Economics, 25(7), pp. 701-708. 
Durdyev, S., Ihtiyar, A., Banaitis, A. and Thurnell, D. 2018. The construction client satisfaction model: a PLS-SEM approach. Journal of Civil Engineering and Management, 24(1), pp. $31-42$.

Edum-Fotwe, F.T. and McCaffer, R., 2000. Developing Project Management Competency: Perspectives from the construction industry. International Journal of Project Management, 18(2), pp. 111-124.

Fornell, C (1992) A National customer satisfaction barometer: The Swedish experience. Journal of Marketing, 56(1), pp. 6-21.

Gruneberg, S.L. 1997. Construction Economics: An introduction. London: Macmillan.

Guest, G., MacQueen, K.M. and Namey, E.E. 2011. Applied Thematic Analysis. London: SAGE.

Gunning, J.G. (2000) Models of customer satisfaction and service quality as research instruments in construction management. In: A. Akintoye (ed.) Proceedings of Sixteenth ARCOM Annual Conference, Glasgow, 6-8 September, pp. 21-30.

Haddadi, A., Johansen, A. and Andersen, B. 2016. A Conceptual Framework to Enhance Value Creation in Construction Projects. Procedia Computer Science, 100(2016), pp. 565-573.

Hazır, Ö. 2015. A review of analytical models, approaches and decision support tools in project monitoring and control. International Journal of Project Management, 33(4), pp. 808815.

Jha, K.N. and Iyer, K.C. 2007. Commitment, coordination, competence and the iron triangle. International Journal of Project Management, 25(5), pp. 527-540.

Jonker, J. and Pennink, B. 2010. The Essence of Research Methodology: A Concise Guide for Master and PhD Students in Management Science. London: Springer. 
Kärnä, S. 2004. Analysing customer satisfaction and quality in construction - the case of public and private customers. Nordic Journal of Surveying and Real Estate Research, Volume 2(Special series), pp. 67-80.

Kärnä, S. and Junnonen, J.M. 2016. Benchmarking construction industry, company and project performance by participants' evaluation. Benchmarking: An International Journal, 23(7), pp. 2092-2108.

Krauss, S.E. 2005. Research Paradigms and Meaning Making: A Premier. The Quantitative Report, 10(4), pp. 758-770.

Kuada, J. 2012. Research Methodology: A project guide for university students. Frederiksberg: Samfundslitteratur.

Kumar, V. and Reinartz, W. 2018. Customer Relationship Management: Concept, strategy, and tools. Berlin: Springer.

Lai, I.K.W. and Lam, F.K.S. 2010. Perception of various performance criteria by stakeholders in the construction sector in Hong Kong. Construction Management and Economics, 28(4), 377-391.

Loosemore, M. 2014. Improving Construction Productivity: A subcontractor's perspective, Engineering, Construction and Architectural Management, 21(3), pp. 245-260.

Lindhard, S. and Larsen, J.K., 2016. Identifying the key process factors affecting project performance. Engineering, Construction and Architectural Management, 23(5), pp. 657673.

Mackey, A. and Gass, S.M. 2015. Second Language Research: Methodology and design. London: Routledge.

Manley, K. and Chen, L. 2015. Collaborative learning model of infrastructure construction: a capability perspective. Construction Innovation, 15(3), pp. 355-377. 
Mbachu, J. and Nkado, R., 2006. Conceptual framework for assessment of client needs and satisfaction in the building development process. Construction Management and Economics, 24(1), pp. 31-44.

Meng, X. 2012. The effect of relationship management on project performance in construction. International Journal of Project Management, 30(2), pp. 188-198.

Merriam, S.B. and Tisdell, E.J. 2015. Qualitative Research: A guide to design and implementation. San Francisco, CA: John Wiley \& Sons.

Ngulube, P. 2015. Qualitative data analysis and interpretation: systematic search for meaning; In Mathipa, E.R. \& Gumbo, M.T. (eds). Addressing research challenges: making headway for developing researchers. New Jersey: John Wiley \& Sons, pp. 131-156.

Nguyen, L.H. and Watanabe, T. 2017. The impact of project organisation culture on the performance of construction projects. Sustainability, 9(5), pp. 1-21.

Nguyen, L.D.; Ogunlana, S.O. and Lan, D.T.X. 2004. A study on project success factors in large construction projects in Vietnam. Engineering, Construction and Architectural Management, 11(6): pp. 404-413.

Nikakhtar, A., Hosseini, A.A., Wong, K.Y. and Zavichi, A. 2015. Application of lean construction principles to reduce construction process waste using computer simulation: a case study. International Journal of Services and Operations Management, 20(4), pp. 461-480.

Oliver, R. and Linda, G. 1981. Effect of satisfaction and its antecedents on consumer preference and intention. Advances in Consumer Research, 8(1), pp. 88-93.

Olsen, W. 2011. Data Collection: Key Debates and Methods in Social Research. London: SAGE. 
Omonori, A. and Lawal, A. 2014. Understanding customers' satisfaction in construction industry in Nigeria. Journal of Economics and Sustainable Development, 5(25), pp. 115120.

Oppong, G.D., Chan, A.P. and Dansoh, A. 2017. A review of stakeholder management performance attributes in construction projects. International Journal of Project Management, 35(6), pp. 1037-1051.

Peppers, D. and Rogers, M. 2016. Managing customer experience and relationships: A strategic framework. New Jersy: John Wiley \& Sons.

Pheng, L.S. and Teo, J.A., 2004. Implementing total quality management in construction firms. Journal of Management in Engineering, 20(1), pp. 8-15.

Raham, A. and Alzubi, Y. 2015. Exploring key contractor factors influencing clients satisfaction level in dealing with construction project: An empirical study in Jordan. International Journal of Academic Research in Business and Social Sciences, 5(12), pp. 109-126.

Rashvand, P. and Majid, M.Z.A. 2014. Critical criteria on client and customer satisfaction for the issue of performance measurement. Journal of Management in Engineering 30(1), 1018.

Sarhan, J.G., Xia, B., Fawzia, S. and Karim, A. 2017. Lean construction implementation in the Saudi Arabian construction industry. Construction Economics and Building, 17(1), pp. 46- 69.

Saunders, L.W., McCoy, A.P., Kleiner, B.M., Lingard, H., Cooke, T., Mills, T., Blismas, N. and Wakefield, R. 2016. International Benchmarking for Performance Improvement in Construction Safety and Health. Benchmarking: An International Journal, 23(4), pp. 916936. 
Scruggs, T.E. and Mastropieri, M.A. 2006. Applications of Research Methodology. London: Emerald Group Publishing.

Shan, Y., Goodrum, P.M., Zhai, D., Haas, C. and Caldas, C.H. 2011. The impact of management practices on mechanical construction productivity. Construction Management and Economics, 29(3), pp. 305-316.

Soetanto, R. and Proverbs, D.G., 2002. Modelling the satisfaction of contractors: the impact of client performance. Engineering, Construction and Architectural Management, 9(5/6), pp. 453-465.

Soetanto, R. and Proverbs, D.G. (2004) Intelligent models for predicting levels of client satisfaction. Journal of Construction Research, 5(2), pp.233-255.

Soetanto, R.; Proverbs, D.G. and Holt, G.D. (2001). Achieving quality construction projects based on harmonious working relationships. Clients' and architects' perceptions of contractor performance. International Journal of Quality and Reliability Management, 18(5), pp. 528-548.

Supino, P.G. and Borer, J.S. 2012. Principles of Research Methodology: A guide for clinical investigators. London: Springer.

Tang, S.L.; Lu, M. and Chan, Y.L. 2003. Achieving client satisfaction for engineering consulting firms. Journal of Management in Engineering, 19(4), 166-172.

Thomas, G. 2017. How to Do Your Research Project: A guide for students. London: Sage.

Thomson, D. 2011. A pilot study of client complexity, emergent requirements and stakeholder perceptions of project success. Construction Management and Economics, 29(1), 69-82.

Torbica Z.M. and Stroh R.C. (2001). Customer Satisfaction in Home Building. Journal of Construction Engineering and Management, 127(1), pp. 82-86.

Trigunarsyah, B. and Al Solaiman, S. 2016. The Impact of Client Involvement on Project Performance: Case of the Kingdom of Saudi Arabia. In Achour, N. (Ed.) Proceedings of 
CIB World Building Congress; Volume V-Advancing products and services. Tampere University of Technology, pp. 258-269.

Walker, A. 2015. Project management in construction. New Jersey: John Wiley \& Sons.

Wetcher-Hendricks, D. 2011. Analyzing Quantitative Data: An introduction for social researchers. London: John Wiley \& Sons.

Wu, C., Wang, F., Zou, P.X. and Fang, D. 2016. How safety leadership works among owners, contractors and subcontractors in construction projects. International Journal of Project Management, 34(5), pp. 789-805.

Yin, R. K. 2013. Case Study Research: Design and Methods (Applied Social Research Methods) (5th edn.). London: Sage.

Yun, J.J., Won, D. and Park, K. 2016. Dynamics from open innovation to evolutionary change. Journal of Open Innovation: Technology, Market, and Complexity, 2(1), pp. 222.

Zhou, Z., Goh, Y.M. and Li, Q. 2015. Overview and analysis of safety management studies in the construction industry. Safety Science, 72(February), pp. 337-350. 